\title{
Studi Sistematik Aspek Kreativitas dalam Konteks Pendidikan
}

\author{
Silmi Amrullah ${ }^{1}$, Lidwina Felisima Tae ${ }^{2}$, Feri Indra Irawan ${ }^{3}$, Zulmi Ramdani $^{4}$, Bagus Hary Prakoso ${ }^{5}$ \\ ${ }^{1}$ Universitas Pendidikan Indonesia (UPI) Bandung \\ ${ }^{2}$ Universitas Timor, Nusa Tenggara Timur \\ ${ }^{3,4}$ UIN Sunan Gunung Djati Bandung \\ ${ }^{5}$ Center for Educational Assessment, Ministry of Education and Culture \\ e-mail: zulmiramdani@uinsgd.ac.id
}

\begin{abstract}
The success of learning in school is determined by the ability to find and use effective and creative learning strategies. Creativity is not only an important element in solving problems, but also an indicator that individuals have higher levels of excellence functions. Creativity character is one of the issues that has not been widely discussed and actualized in the context of education, especially in the focus of creating an effective learning process. A systematic review was used to examine previous research on creativity in the context of education. This study reviewed 450 scientific papers based on the analysis of the three experts who participated in the study. The results show that creativity has a specific model based on aspects of definition, characteristics of creative subjects, supporting factors, inhibiting factors, domain of creativity and creative strategies in school. Creativity is also a very important character and has a particular model both for students and teachers, and for the principals.
\end{abstract}

Keywords: creativity, good education, systematical review

\begin{abstract}
Abstrak
Keberhasilan belajar di sekolah ditentukan oleh kemampuan untuk menemukan dan menggunakan strategi pembelajaran yang efektif atau kreatif. Kreativitas bukan hanya elemen penting dalam menyelesaikan masalah, tetapi juga merupakan indikator bahwa individu memiliki tingkat keunggulan fungsi yang lebih tinggi dengan sangat baik. Keberadaan karakter kreativitas adalah salah satu isu yang belum banyak dibahas dan direalisasikan dalam konteks pendidikan, terutama dalam menciptakan proses pembelajaran yang efektif. Hal ini disebabkan kurangnya pemahaman yang komprehensif tentang kegiatan belajar berdasarkan kreativitas. Suatu pendekatan tinjauan sistematis digunakan dalam penelitian ini dengan meninjau dan mengeksplorasi sebanyak 450 artikel ilmiah berdasarkan hasil dan analisis dari tiga ahli yang berpartisipasi dalam penelitian ini. Hasil penelitian menunjukkan bahwa kreativitas memiliki model spesifik berdasarkan aspek definisi, karakteristik subjek kreatif, faktor pendukung, faktor penghambat, domain kreativitas dan strategi kreativitas di sekolah. Selain itu kreativitas juga merupakan karakter yang sangat penting dan memiliki model khusus baik untuk siswa, guru, dan untuk kepala sekolah.
\end{abstract}

Kata Kunci: kreativitas, pendidikan yang baik, studi sistematik

\section{Pendahuluan}

Keberhasilan sebuah pendidikan di sekolah bukan hanya dimulai dari kebijakan, pemerataan, dan sistem yang sudah terintegrasi semata melainkan juga adalah kolaborasi dari elemen-elemen penting di dalam sekolah tersebut. Kolaborasi yang dimaksud meliputi peran dan kekuatan kepala sekolah dalam menciptakan iklim sekolah yang baik, guru sebagai pendidik sekaligus pengajar yang menjadi ujung tombak terciptanya generasi muda yang berkualitas, serta siswa sebagai subjek pendidikan yang akan berperan sebagai pemimpin dan generasi penerus di masa depan (Ramdani, 2018). Salah satu aspek yang dianggap penting dan menjadi karakteristik yang sudah seharusnya ada dalam diri elemen-elemen tersebut adalah kreativitas. Berdasarkan hasil studi sebelumnya, bahwa aspek kreativitas adalah aspek yang berperan tidak hanya menjadi- 
kan pendidikan itu lebih menarik, tetapi juga menjadi indikator bahwa setiap individu di dalamnya itu aktif dan mampu mengembangkan potensi terbaiknya yang kemudian ini akan berpengaruh terhadap keberhasilan pendidikan di masa depan (Ramdani, 2018).

Aspek kreativitas banyak dibahas dalam berbagai setting kehidupan manusia terutama dalam disiplin ilmu Psikologi Positif. Secara teoretis kreativitas mengarahkan individu untuk mencapai tujuan dengan caranya sendiri yang baru, unik, dan orisinil (Peterson \& Seligman, 2004). Ide ataupun perilaku tersebut harus adaptif, yaitu harus dapat memberikan kontribusi yang positif bagi diri sendiri dan orang lain (Peterson \& Seligman, 2004). Dalam konteks pendidikan sendiri, berpikir kreatif termasuk ke dalam higher level of executive functions manusia, dimana aspek ini berperan dalam menyelesaikan permasalahan yang kompleks dan berguna dalam menghadapi situasi yang sulit dan tertekan (Delis, Lansing, Houston, Wetter, Han, Jacobson, \& Kramer, 2007). Selain itu pengajaran yang kreatif akan melandasi siswa untuk berpikir kreatif yang kemudian menjadi indikator bahwa sebagai individu yang utuh tidak hanya mampu menyelesaikan masalah dengan tuntas, di sisi lainnya menjadi pertanda bahwa kepribadian, pengetahuan, dan motivasi berpengaruh terhadap lingkungan mereka (Strenberg, 2006).

Pada kenyataannya aspek kreativitas ini menjadi salah satu karakteristik yang belum sepenuhnya dibangun dalam dunia pendidikan. Studi yang dilakukan terhadap mahasiswa berprestasi menunjukkan bahwa aspek ini jauh belum banyak diperhatikan oleh mahasiswa terutama di dalam aktivitas akademik mereka (Ramdani \& Fahmi, 2014). Tidak hanya pada siswa, rendahnya karakteristik dari kreativitas ini juga terjadi pada guru yang mengajar di sekolah yang ditunjukkan dengan skor paling rendah pada skala Values in Action Inventory Scales (VIA-IS) dibandingkan karakteristik lainnya seperti keterbukaan pikiran dan kecintaan terhadap belajar (Ramdani, 2018). Tujuan dari penelitian ini adalah untuk mengkaji dan melakukan review artikelartikel ilmiah dan mendapatkan pemahaman konsep tentang aspek-aspek kreativitas dalam konteks pendidikan.

\section{Metode Penelitian}

Penelitian ini menggunakan pendekatan kualitatif berbasis systematic review. Metode ini dilakukan dengan cara mengumpulkan tulisan ilmiah dari berbagai mesin atau data base yang terkait topik kreativitas di sekolah (Ashford, Edmunds, \& French, 2010). Pada tahap ini, peneliti mengumpulkan berbagai tulisan ilmiah dengan menggunakan bantuan mesin data base science direct, sage, dan ebscohost.

Peneliti menggunakan keyword diantaranya adalah "creative climate", "creative in school", "elements of creativity", "teacher's creativity", "teaching with creativity", "innovation in school", "school's creativity", "schools leaderships inovations", "sources of creativity", "creativity of schools principals", "students creativity" dan "creative education". Kemudian proses selanjutnya adalah melakukan judgement dan selection untuk mendapatkan artikel-artikel yang relevan dengan tujuan penelitian.

\section{Hasil Penelitian dan Pembahasan}

\section{Hasil Penelitian}

Berdasarkan hasil review, 53 artikel dipilih sebagai artikel-artikel yang paling relevan dengan penelitian ini. Selanjutnya, aspek-aspek penting tentang kreativitas dikelompokkan menjadi 6 tema besar yang akan dijelaskan pada hasil dan diskusi di bawah ini. 
Collecting Data (450 tulisan ilmiah\}

Judging \& Selecting Data (Dibagi menjadi 3 data yang akan diolah oleh 3 expert)

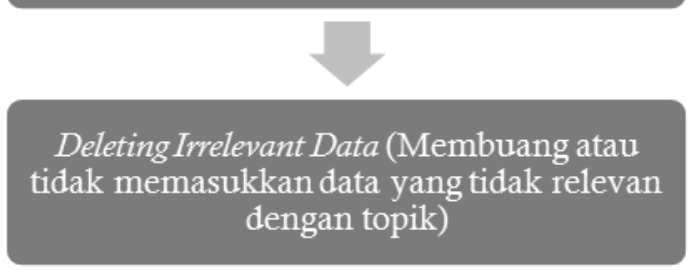

Validating Data (Tiap-tiap expert

mendapatkan kurang lebih 50 artikel yang relavan berdasarkan abstrak artikelnya yaitu kreativitas di sekolah)

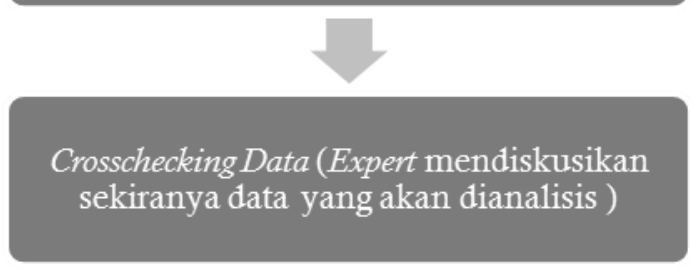

Analyzing Data (Data hasil crosscheck dikaji oleh tiap expert berdasarkan temuan-temuan atau urgensi mengenai konsep kreativitas yang harus ada di sekolah

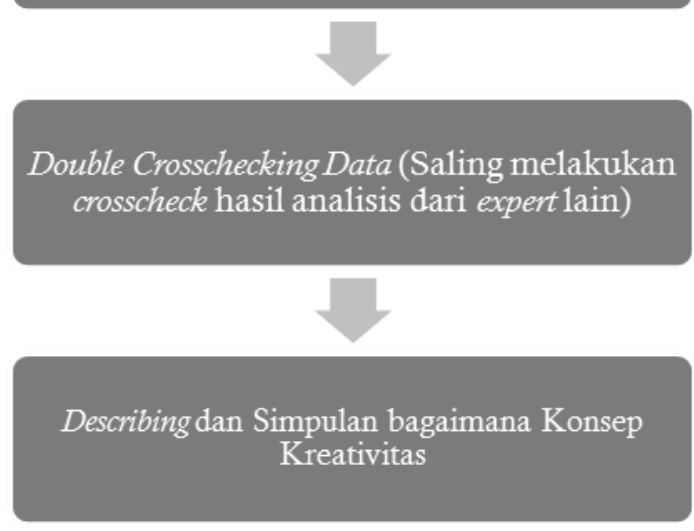

Gambar 1. Alur Studi Sistematik

Definisi kreativitas. Kreativitas didefinisikan secara luas dan kompleks dengan berbagai macam sudut pandang yang ditemukan dalam artikel-artikel ini. Kreativitas awalnya didefinisikan sebagai intelegensi yang bersifat bawaan yang kemudian berkembang menjadi hasil dari perpaduan kemampuan bawaan seseorang dan proses adaptasi dengan lingkungan (Jahnke, Haertel, \& Wildt, 2017). Pengertian kreativitas kemudian meluas, dimana kreativitas dipandang sebagai level tertinggi dalam mengekspresikan sebuah ide baru dan kemampuan untuk mengkombinasikan topik-topik yang tidak saling berhubungan dengan cara yang berbeda untuk menghindari pola-pola yang sudah umum (Krumm, Aranguren, Arán Filippetti, \& Lemos, 2016). Hal ini berarti kreativitas diasosiasikan dengan proses mengeksploitasi kemungkinankemungkinan yang mungkin saja bertentangan dengan cara-cara yang konvensional (Taylor \& Callahan, 2005), kesediaan/ kemauan untuk menerima sesuatu yang baru, dan kemauan untuk menerima risiko dan tidak takut pada tantangan (Jahnke dkk., 2017).

Secara lebih rinci, Lucas (2016) mengelompokkan lima model kreativitas yang dikembangkan, yaitu imaginative (bermain dengan kemungkinan, membuat koneksi, menggunakan intuisi), inquisitive (berkhayal dan bertanya, mengeksplor dan investigasi, tantangan), persistent (unik, bertahan dalam kesulitan, dan toleransi), collaborative (memberi dan menerima masukan, kerjasama yang tepat, berbagi hasil), dan disiplin (refleksi terhadap kritikan, mengembangkan teknik, pengembangan diri). Sedangkan pada pengelompokkan yang lain, kreativitas dibagi menjadi tiga perspektif yaitu originality (menyelesaikan sesuatu dengan cara yang belum pernah dilakukan sebelumnya), novelty (menciptakan sesuatu yang baru) dan difference atau melihat sesuatu dalam sudut pandang yang berbeda (Jauk, Benedek, \& Neubauer, 2014).

Beberapa aspek lain juga ditambahkan dalam kreativitas, seperti kelancaran (banyaknya ide), fleksibilitas (keragaman ide), keaslian baru dan bergunanya suatu ide (Warren, Mason-Apps, Hoskins, Azmi, \& 
Boyce, 2018), imagination, motivasi positif, serta kemandirian (Maksić \& Pavlović, 2011). Selain itu, Agnoli, Zanon, Mastria, Avenanti, \& Corazza (2018) juga menambahkan motivasi intrinsik pada diri siswa dan pengaruh lingkungan (di dalam dan luar sekolah) yang dapat memrediksi pencapaian/ prestasi siswa yang kreatif. Secara lebih filosofis Collard \& Looney (2014) mengemukakan bahwa kreativitas merupakan perkembangan mendasar pada individu yang akan memengaruhi kebahagiaan mereka di dalam kehidupan. Hal-hal ini dimulai dari kemampuan di dalam menggunakan rasa, imaginasi, berpikir dan beralasan, serta mencoba untuk melakukan apa yang ada dalam kapasitas mereka.

Ciri orang kreatif. Berdasarkan hasil review, ditemukan berbagai macam kata kunci yang menandakan seseorang itu kreatif. Ciri-ciri individu yang kreatif adalah mereka yang imaginatif, memiliki rasa ingin tahu yang besar, kemauan untuk mengeksplorasi sesuatu yang tidak diketahui, menyukai tantangan, tidak takut mencoba sesuatu yang baru dan memiliki kemampuan untuk memahami ambiguitas. Individu yang kreatif memiliki usaha dan keteguhan, mempunyai efikasi diri yaitu kepercayaan diri yang besar terhadap kemampuan yang dimiliki (Collard \& Looney, 2014; Zhou, Shen, Wang, Neber, \& Johji, 2013).

Individu yang kreatif juga adalah mereka yang tertarik pada ide-ide yang baru dan kompleks, berpikir secara abstrak, menggeneralisasi ide, meramalkan kemungkinan, menganalisis sebuah gambaran yang besar/ menyeluruh, imajinasi yang tidak biasa dan pemimpi, suka permainan yang intelek, rasa keingintahuan, menemukan kesenangan ketika bermain dengan ideide, kemampuan untuk menawarkan banyak solusi dengan berbagai sudut pandang, berani mengambil risiko, konsisten untuk mencoba terus sesuatu yang baru, hiperaktif atau energi yang ekstrim dan mempunyai konsep diri yang lebih positif
(Taylor \& Callahan, 2005). Sementara itu, menurut Runco, Millar, Acar, \& Cramond (2010) kreativitas adalah ketika seseorang menghadapi masalah yang belum pernah dipelajari sebelumnya namun dia tahu bagaimana cara menyelesaikannya. Selanjutnya orang yang kreatif juga diasosiasikan sebagai orang yang berorientasi kepada tugas, pekerja keras dan mampu bertahan dalam waktu lama untuk mencapai target tertentu. Mereka juga memiliki keinginan untuk mengejar kepercayaan mereka dan berani untuk mengambil risiko untuk ini.

Selain itu, ciri-ciri lain yang terlihat adalah mereka memiliki motivasi intrinsik yang sangat tinggi untuk menjadi kreatif di bidang mereka. Memiliki disiplin diri yang sangat tinggi dan sangat berdedikasi terhadap pekerjaan mereka. Memiliki kepercayaan yang mendalam tentang apa yang mereka tekuni. Memiliki standar yang tinggi untuk pekerjaan yang mereka lakukan, berpikir divergen, memiliki pengetahuan yang ekstensif tentang bidang tertentu dan memiliki komitmen terhadap pekerjaan mereka. Juga mereka memiliki pemikiran yang fleksibel, yang selalu mencari situasi yang baru dan memikirkan banyak kemungkinan (Taylor \& Callahan, 2005).

Secara lebih mendetail, Boytos, Smith, \& Kim (2017) mengelompokkan individu yang kreatif menjadi dua kelompok, yaitu underdog dan topdog. Underdog adalah orang yang berjuang keras untuk mendapatkan sesuatu yang tidak mereka miliki, sedangkan topdog adalah orang yang memertahankan apa yang sudah mereka miliki. Sedangkan Kaufman \& Beghetto (2013) mengklasifikasikan level-level kreativitas menjadi 4 tingkatan, yaitu: big$C$ atau eminent creativity, yang dimiliki oleh seniman atau ilmuwan yang hebat, pro- $C$ atau level expert kreativitas, yaitu kreativitas yang ditunjukkan pada profesional level terutama oleh para kreator/ pencipta yang belum mendapatkan eminent status. little- $C$ atau kreativitas sehari-hari yang mengatur kreativitas seseorang dalam hidup dan pengalaman sehari-hari. mini- $C$ 
yaitu kreativitas yang subjektif dimana menggambarkan bagaimana seseorang memiliki pengertian/ pengetahuan yang baru dan bermakna selama proses pembelajaran dan pengalaman.

Faktor pendukung kreativitas. Tingkatan kreativitas yang ada pada seorang individu dipengaruhi oleh beberapa faktor. Status sosial dan ekonomi sebuah keluarga dapat memengaruhi perkembangan kreativitas seseorang. Beberapa penelitian mendukung bahwa keluarga dengan kedudukan sosial dan ekonomi yang baik mampu menghasilkan seorang anak yang lebih kreatif (Castillo-Vergara, AlvarezMarin, \& Placencio-Hidalgo, 2018). Status sosial-ekonomi keluarga dan dukungan ekstrinsik (misalnya aktivitas intelektual di rumah seperti ketersediaan buku di rumah) mempunyai pengaruh positif terhadap level kreativitas siswa. Selain itu, lingkungan juga memiliki pengaruh yang sangat besar, dimana beberapa penelitian menemukan bahwa sebuah lingkungan yang mendukung proses kreatif siswa (misalnya di rumah maupun di sekolah) dapat mengembangkan kreativitas siswa dengan lebih baik. Namun demikian, pengaruh faktor-faktor ini hanya ada pada saat tahap awal (saat masih anakanak). Pengaruh faktor-faktor luar ini tidak lagi berdampak saat seorang siswa bertumbuh dewasa. Sementara itu, motivasi intrinsik dari orang tua (misalnya membantu anak mengidentifikasi kesalahan mereka daripada memberikan hadiah) ditemukan tidak memberikan efek apa-apa terhadap perkembangan kreativitas seorang anak (Gralewski \& Karwowski, 2018).

Sebuah lingkungan sosial yang suportif juga dapat memengaruhi kreativitas siswa. Siswa yang mendapatkan dukungan dari sekolah untuk mengembangkan kreativitas, mereka memiliki self-efficacy yang lebih kreatif dan menjadi seorang individu yang kreatif (Chang, Wang, \& Lee, 2016). Adanya ruang/ space bagi siswa untuk mengembangkan berpikir kreativitas mereka seperti ruang pribadi, ruang untuk diskusi kelompok, ruang untuk eksperimen, dan ruang untuk interaksi sosial (seperti kafe dan taman) memberikan pengaruh positif terhadap perkembangan kreativitas siswa (Castillo-Vergara dkk., 2018). (Gulliksen, 2017) juga menemukan bahwa ada sebuah hubungan yang erat antara permainan dan lingkungan terhadap kreativitas.

Secara lebih jauh, ditemukan bahwa kreativitas yang ada dalam diri seseorang dapat memrediksi prestasi siswa di sekolah. Sebuah penelitian longitudinal menemukan bahwa seseorang dengan tingkat IQ yang rendah memiliki kemungkinan kecil untuk menghasilkan individu yang memiliki pencapaian kreatif yang tinggi. Walaupun demikian, IQ yang tinggi tidak otomatis menjamin pencapaian kreativitas yang tinggi (Gralewski \& Karwowski, 2018). Penelitian lain juga mengungkapkan bahwa kecerdasan emosional (EI) tidak memiliki pengaruh apapun terhadap performa ataupun pencapaian siswa (Hansenne \& Legrand, 2012). Selain itu, beberapa penelitian juga membuat hubungan antara kreativitas dengan pencapaian akademik seseorang di sekolah dan menemukan bahwa ada link yang negatif antara prestasi sekolah (GPA) dan kreativitas (Gajda, 2016).

Suasana pembelajaran berbasis kreativitas. Pembelajaran yang kreatif didefinisikan sebagai pertukaran pengetahuan yang unik, terencana, dan berarti antara seluruh elemen pendidikan pada individu. Beberapa hal yang bisa dilakukan dalam melakukan pengajaran yang kreatif yaitu: lebih banyak melibatkan siswa (menghubungkan antara materi yang diajarkan dengan kehidupan nyata); ketepatan dalam menggunakan konsep kreativitas di kelas (membedakan beragam jenis kreativitas); memberikan siswa instruksi yang jelas sehingga mereka mampu menjelaskan secara spesifik suatu pelaksanaan kegiatan dengan kreatif); dan memanfaatkan kesempatan-kesempatan belajar kreatif yang authentic seperti mengevaluasi sejauhmana level kreativitas siswa 
dengan melihat korelasinya pada hasil pembelajaran (Rinkevich, 2011).

Beberapa penelitian juga menempatkan kompetensi guru sebagai salah satu faktor penting untuk menciptakan pembelajaran yang kreatif. Chan \& Yuen (2014) menemukan bahwa guru-guru yang biasanya mengajar pada kelas dengan siswa yang genius memiliki skor kreatif yang lebih tinggi. Ini disebabkan guru-guru ini memiliki kepercayaan terhadap kreativitas mereka yang baik, kepribadian yang kreatif, dan pada akhirnya memengaruhi perilaku kreativitas mereka.

Sedangkan, beberapa penilaian menemukan sistem untuk menganalisis program kreativitas, antara lain: tes psikometri mengenai berpikir divergen, tes perilaku atau kepribadian masa lalu atau karakteristik kepribadian, tes kepribadian yang berkorelasi dengan perilaku kreatif, daftar aktivitas yang berkaitan dengan produksi kreatif, menguji skala sikap kreatif, menggunakan teknik yang canggih dalam karya kreatif, penilaian ahli dalam menilai level kreativitas dari karya atau respon, dan penilaian konsumen (Lucas, 2016).

Tingkat kreativitas juga bisa dilihat dari sejauhmana siswa di era modernisasi menggunakan kemajuan teknologi sebagai wadah kreativitas mereka. Kreativitas di era digital dapat dilihat dari 3 faktor, pertama adalah prestasi atau kegiatan mereka yang dapat berkaitan dengan aktivitas yang kreatif, kedua adalah aktivitas kreativitas yang sering mereka lakukan di sekolah, dan yang ketiga adalah aktualisasi diri mereka terhadap kreativitas digital (Hoffmann, 2016; Delis dkk., 2007).

Beberapa cara dapat dilakukan di sekolah untuk meningkatkan kreativitas diantaranya adalah metode dan cara belajar yang digunakan, perkembangan profesionalitas, memromosikan kreativitas, identifikasi dan menuntut siswa dengan program ekstrakurikuler, serta jawabanjawaban yang tidak spesifik atau general answer (Maksić \& Pavlović, 2011).
Guru yang kreatif akan menghasilkan suasana belajar yang efektif, mengarahkan kelas pada suasana intelektual yang baik., meningkatkan kemandirian, kepercayaan diri dan pertumbuhan personal diri anak. Ciri-ciri guru yang kreatif dilihat dari beberapa aspek yaitu: pertama, aspek pembelajaran (presentasi yang menarik, pentingnya belajar, aplikasi keilmuan dengan kegiatan sehari-hari, dan menggunakan cerita sebagai pembelajaran). Kedua, manajemen kelas (mengubah ukuran kelas dan mengadakan sesi kelas di luar). Ketiga, tugas (tugas-tugas yang kreatif dan tugas kelompok yang kreatif). Keempat, interaksi dengan siswa (menguatkan siswa untuk berani bertanya, menggunakan kemampuan mendasar siswa, dan memberikan feedback positif). Kelima, karakter guru yang aktif dan antusias, tertarik dan perhatian, berpikir luas dan aktif mendengar (Abedini \& Broujeni, 2016). Hal ini disebabkan kreativitas anak-anak di hadapan guru mereka dilihat dari pembelajaran yang menggunakan self-reflective, proses pembelajaran yang mandiri, menunjukkan motivasi dan keingintahuan yang besar, menciptakan atau menghasilkan sesuatu, menunjukkan banyak atau lebih dari satu perspektif, mencapai originalitas dari ideide baru dan melakukan dengan maksimal (Jahnke dkk., 2017).

Iklim kreatif di sekolah. Beberapa artikel menekankan perlu adanya lingkungan kreatif yang akan membantu individu belajar dan menyediakan siswa dukungan yang mereka butuhkan untuk berpikir secara terbuka dan secara produktif. Kreatif muncul dari sekumpulan ide, campuran perasaan, kata-kata, dan perbuatan yang saling terkait satu sama lain dalam dunia mereka. salah satunya bisa dilihat ketika mereka diberikan suatu permasalahan dan bagaimana mereka menyelesaikan permasalahan tersebut dengan berbagai jenis solusi. Salah satu hal yang membuat mereka kreatif adalah proses berpikir kritis yang harus dilakukan. Dengan lingkungan dan bimbingan yang 
benar, siswa bisa diajak untuk menyelesaikan permasalahan dan tidak takut akan salah. Karena kreativitas ini berkaitan dengan fungsi tertinggi dalam berpikir maka dibutuhkan proses yang sistematis untuk menilainya (Castillo-Vergara dkk., 2018).

Faktor penghambat kreativitas. Beberapa faktor penghambat kreativitas yang ditemukan dalam artikel antara lain, hubungan sosial yang tidak mendukung kreativitas, pandangan budaya, lingkungan yang tidak suportif, hambatan yang berasal dari dalam diri orang tersebut, pola pendidikan, hubungan sosial dan pandangan budaya, lingkungan dan hambatan yang berasal dari dalam diri seseorang.

Beberapa kategori umum yang juga disinyalir menjadi penghambat dalam pendidikan berbasis kreativitas adalah sumber daya dan lingkungan alam, sumber daya dan lingkungan pendidikan, kualifikasi dan kepribadian pendidik serta kualifikasi dan kepribadian siswa. Sumber daya dan lingkungan alam meliputi kehilangan dan ketidakcocokan teknik yang digunakan, kehilangan dan ketidakcocokan fasilitas dan infrastruktur yang ada. Sumber daya dan lingkungan pendidikan meliputi kekurangan waktu dan tekanan, kurikulum yang tidak sesuai, siswa yang terlalu banyak serta sistem pendidikan yang belum baik. kualifikasi dan kepribadian pendidik meliputi ketidakcocokan cara mengajar dan perilaku, kurang dalam memahami pengetahuan dan pengalaman serta bimbingan, sifat-sifat negatif yang masih ada. Kualifikasi dan kepribadian siswa meliputi sifatsifat yang negatif, serta kehilangan pengetahuan dan kemampuan dasar (Elisavet Konstantinidou, Gregoriadis, Grammatikopoulos, \& Michalopoulou, 2014).

Selain itu, rintangan-rintangan lainnya dalam kreativitas diantaranya adalah kurikulum, penilaian dan pengajaran, pelatihan terhadap guru, perkembangan media, serta kepemimpinan dan budaya pendidikan.
Apa yang seharusnya dilakukan sekolah yaitu dengan mendukung guru-guru untuk mengambil tugas-tugas yang menantang dan berisiko, meyakinkan siswa dengan saran dan masukan yang positif dan juga dukungan untuk berkembang, serta menguatkan kolaborasi antara stakeholder di sekolah (Collard \& Looney, 2014). Secara ringkas, hasil review paper tentang kreativitas ditampilkan pada bagan di bawah ini.

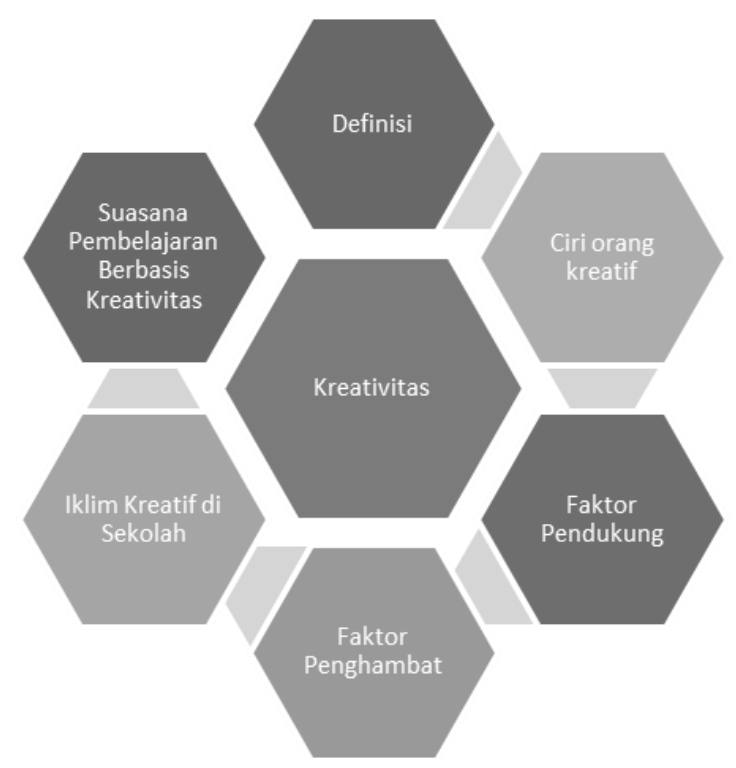

Gambar 2. Conceptual Framework of Creativity

\section{Pembahasan}

Kreativitas adalah bahasan yang sangat penting di era modernisasi dan kemajuan teknologi saat ini karena menjadi salah satu hal yang menentukan kualitas pendidikan dan perkembangan kemampuan anak di sekolah. Penelitian-penelitian yang dibahas dalam studi ini memberikan gambaran yang jelas mengenai pentingnya krearivitas dalam beragam aktivitas manusia. Kreativitas adalah suatu konsep yang sangat luas secara makna, sehingga perlu digambarkan dan diperinci ke dalam bentuk penjelasan yang lebih operasional. Kreativitas didefinisikan sebagai kemampuan yang fleksibel yang berfokus pada proses dengan menggunakan fungsi berpikir paling tinggi pada manusia (Zhou dkk., 2013). Proses seperti ini mengharuskan setiap individu untuk 
berpikir adaptif dan solutif terhadap berbagai permasalahan yang ada. Karena sifatnya yang begitu kompleks, maka tidak ada satupun pengukuran yang mampu melihat konstruk kreativitas secara langsung atau holistik (Lucas, 2016). Sehingga banyak ahli yang mengatakan bahwa orang yang beraktivitas secara kreatif adalah mereka yang mempunyai kemampuan intelektual yang tinggi (Abdulla \& Cramond, 2017). Secara sederhana kreatif muncul dalam sekumpulan ide, campuran perasaan, kata-kata, dan perbuatan yang saling terikat satu dengan yang lainnya dalam menyelesaikan suatu pekerjaan atau masalah (E Konstantinidou, Zisi, Katsarou, \& Michalopoulou, 2015).

Perspektif lainnya menjelaskan kreativitas sebagai fungsi eksekutif yang meliputi kemampuan mendasar pada manusia terutama dalam berpikir sesuatu hal yang bersifat abstrak (Hoffmann, Ivcevic, \& Brackett, 2016). Hal ini yang kemudian menyebar ke dalam diri inidividu yang meliputi kognitif, sosial, emosional, hingga karakter-karakter yang kemudian mengikat pada individu tersebut (Maksić \& Pavlović, 2011).

Kreativitas muncul karena didorong oleh potensi kecerdasan seorang individu di dalam hidupnya yang sudah dibentuk dan diturunkan secara genetik dari orang tua mereka, sehingga level kecerdasan kreativitas ini bergantung pada apa yang orang tua berikan, ajarkan, dan terapkan dalam kehidupan anak-anak mereka (Burns, Zhang, Wieth, \& Touyz, 2017). Kecerdasan yang bersifat bawaan ini kemudian secara bertahap akan menjadi sebuah pengetahuan dasar yang memunculkan kepercayaan diri pada anak (Bush, 2014). Dan yang akan menguatkan atau melemahkan potensi tersebut adalah lingkungan dimana individu tinggal, baik meliputi dimana ia sekolah, seperti apa mereka berinteraksi, bagaimana penyelesaian masalah terhadap kebutuhannya dan konteks lainnya terkait perkembangan individu (Collard \& Looney, 2014).
Terdapat beberapa ciri kreativitas yang dimiliki oleh individu yang kreatif. Secara umum kreativitas digambarkan dalam tiga perspektif yaitu originality, novelty, dan difference (Choi, 2004). Adapun seseorang yang kreatif memiliki karakteristik sebagai berikut: (1) imaginative, (2) keinginan untuk selalu mencoba, (3) berpikir original dan rasa ingin tahu yang besar (de Alencar, 2014). Dalam perspektif lainnya kreativitas dapat dianalisis melalui beberapa karakteristik diantaranya: (1) imaginative (bermain dengan kemungkinan, membuat koneksi, menggunakan intuisi), (2) inquisitive (berkhayal dan bertanya, mengeksplorasi dan investigasi, tantangan), (3) persistent (unik, bertahan dalam kesulitan, toleransi), (4) collaborative (memberi dan menerima masukan, kerjasama yang tepat, berbagi hasil), dan (5) disiplin meliputi refleksi kritikan, mengembangkan teknik, pengembangan diri (Soriano, 1985).

Ciri-ciri kreatif adalah mereka yang memiliki kepribadian dalam bentuk openness to experience, rasa ingin tahu yang besar, kemauan untuk mengeksplorasi sesuatu yang tidak diketahui serta kemampuan dalam memahami ambiguitas (Collard \& Looney, 2014). Openness ini merefleksikan keingintahuan secara intelektual dan kecenderungan untuk menciptakan hal yang baru (Burns dkk., 2017). Kreativitas juga berhubungan dengan keaslian ide, keterbukaan terhadap pengalaman, kesediaan/ kemauan untuk menerima sesuatu yang baru, berbeda dan mungkin saja tidak masuk akal, kemauan untuk menerima risiko dalam pikiran maupun perbuatan, dan sensitif terhadap keindahan karakter dari ide-ide tersebut.

Kreativitas dalam dunia pendidikan tidak terlepas dari dua aspek penting yaitu guru sebagai pendidik dan siswa sebagai peserta didik. Adapun bentuk kreativitas yang dimiliki oleh seorang pendidik dilihat dari beberapa aspek yaitu: pertama, aspek pembelajaran (presentasi yang menarik, pentingnya belajar, aplikasi keilmuan dengan kegiatan sehari-hari, dan meng- 
gunakan cerita sebagai pembelajaran). Kedua, manajemen kelas (mengubah ukuran kelas dan mengadakan sesi kelas di luar). Ketiga, tugas (tugas-tugas yang kreatif dan tugas kelompok yang kreatif). Keempat, interaksi dengan siswa (menguatkan siswa untuk berani bertanya, menggunakan kemampuan mendasar siswa, dan memberikan feedback positif). Kelima, karakter guru yaitu aktif dan antusias, tertarik dan perhatian, berpikir luas dan aktif mendengar (Abedini \& Broujeni, 2016). Sedangkan kreativitas siswa/ peserta didik di hadapan guru mereka dilihat dari: pertama, pembelajaran yang menggunakan self-reflective. Kedua, proses pembelajaran yang mandiri. Ketiga, menunjukkan motivasi dan keingintahuan yang besar. Keempat, menciptakan atau menghasilkan sesuatu. Kelima, menunjukkan banyak atau lebih dari satu perspektif. Keenam, mencapai originalitas dari ide-ide baru. Ketujuh, melakukan dengan maksimal (Jahnke dkk., 2017).

Kreativitas dianggap sebagai sesuatu yang sangat penting dalam era milenial sekarang ini (Lucas, Claxton, \& Spencer, 2013). Cara terbaik untuk berkreativitas di era milenial adalah meningkatkan dan pandai melihat apa yang ada dalam lingkungan global, memanfaatkan media sebagai sumber yang menguntungkan, berani mengambil tantangan dan tidak takut untuk mencoba.

Pemahaman yang mendasar tentang apa itu kreativitas dan bagaimana indikator dari orang-orang yang kreatif kemudian akan menjadi pengetahuan awal dalam menentukan strategi apa yang akan digunakan dalam proses pembelajaran yang dapat meningkatkan kemampuan tersebut. Sekolah sebagai konteks dimana pendidikan itu dibangun, sejak awal sudah seharusnya membangun iklim sekolah yang kreatif, dimana anak diajarkan untuk menghadapi situasi baru dengan penuh keberanian dan kepercayaan diri walaupun hal tersebut di luar ekspektasi anak-anak tersebut (Collard \& Looney, 2014). Dengan iklim seperti itu harapannya anak-anak bisa berkembang dengan penuh optimisme karena mereka sudah dibiasakan dengan berbagai kondisi yang menekan dan menantang yang pada akhirnya mereka akan menggunakan seluruh kemampuannya secara optimal untuk berhasil. Selain itu metode-metode atau strategi yang bisa dilakukan oleh guru ataupun sekolah untuk anak-anak mereka bisa dilakukan dengan beragam aktivitas yang membangun kreativitas seperti pembelajaran yang menggunakan selfreflective, proses pembelajaran mandiri, menunjukkan keingintahuan dan motivasi yang tinggi, menghasilkan sesuatu yang baru dan berusaha bekerja secara maksimal (Abedini \& Broujeni, 2016).

Faktor-faktor pendukung yang berkaitan dengan kreativitas adalah kerja keras individu, pengaruh lingkungan dan kelompok (Seng, Keung, \& Cheng, 2008). Selain itu faktor- faktor lainnya seperti: kemampuan intelektual, pengetahuan, gaya berpikir, motivasi, lingkungan, kepribadian dan komponen individu dalam mengembangkan kreativitas (Strenberg, 2006).

Adanya dorongan atau motivasi intrinsik dan ekstrinsik serta kemampuan sosial ekonomi keluarga dalam menyediakan fasilitas belajar dapat memberikan pengaruh positif terhadap level kreativitas, namun hanya pada saat tahap awal yaitu saat masih anak-anak (Thoring, Desmet, \& BadkeSchaub, 2018). Faktor lain yang lebih mendorong adalah lingkungan sosial yang suportif dapat memengaruhi kreativitas siswa. Siswa yang mendapatkan dukungan dari sekolah untuk mengembangkan kreativitas mereka memiliki self-efficacy yang lebih kreatif dan menjadi seorang individu yang kreatif (Chang dkk., 2016).

Perspektif lain mengungkapkan 3 tantangan yang memengaruhi kreativitas adalah kelancaran (banyaknya ide), fleksibilitas (keragaman ide), keaslian (baru dan bergunanya suatu ide). Dapat disimpulkan bahwa seseorang yang memiliki kreativitas dituntut untuk memiliki keberagaman ide yang bersifat original dan memiliki keber- 
manfaatan (Warren dkk., 2018). Dengan demikian faktor-faktor yang dijelaskan sebelumnya menjadi perhatian serius bahwa konsep kreativitas itu adalah sesuatu yang sangat kompleks dan harus dipahami sangat operasional. Sehingga harapannya dengan memahami apa yang dipaparkan dalam penelitian ini bisa menjadi sumber rujukan dalam memandang kreativitas sebagai aspek yang penting dalam pendidikan.

\section{Simpulan dan Saran}

Berdasarkan hasil review artikel, didapatkan bahwa kreativitas memiliki definisi yang kompleks dengan domain yang luas. Ciri orang yang kreatif berkisar dari kemampuannya untuk berpikir divergen, imaginatif, suka akan tantangan hingga tekun dalam mengerjakan sesuatu. Sedangkan faktor-faktor yang mendorong kreativitas adalah lingkungan (keluarga, masyarakat dan sekolah) dan motivasi dalam diri seseorang. Walaupun demikian pengaruh budaya dan lingkungan juga dapat menghambat perkembangan kreativitas seseorang. Lingkungan sekolah yang kreatif dan pembelajaran dalam kelas yang berbasis kreativitas dapat memengaruhi perkembangan kreativitas seorang siswa.

Hasil penelitian mengenai gambaran konsep kreativitas ini menghasilkan beberapa karakteristik mengenai kreativitas. Disamping beberapa faktor yang dapat mendukung kreativitas, masih ditemukan faktor penghambat kreativitas seperti hubungan sosial yang tidak mendukung kreativitas, pandangan budaya, lingkungan yang tidak mendukung dan hambatan yang berasal dari dalam diri orang tersebut. Penelitian ini menyajikan sebuah kerangka dasar yang bisa dijadikan sebagai rujukan penelitian lainnya dalam konteks lapangan secara langsung. Dengan penggunaan metode dan kajian yang lebih empiris di lapangan, maka hasil dari studi ini sangat tepat dijadikan sebagai rujukan konseptualnya.

\section{Daftar Pustaka}

Abdulla, A. M., \& Cramond, B. (2017). After six decades of systematic study of creativity: What do teachers need to know about what it is and how it is measured? Roeper Review, 39(1), 923.

doi.org/10.1080/02783193.2016.1247 398

Abedini, S., \& Broujeni, R. B. (2016). Teacher creativity in university students, views: A content analysis. International Journal of Pharmaceutical Research \& Applied Sciences, 5(21), 379-386.

Agnoli, S., Zanon, M., Mastria, S., Avenanti, A., \& Corazza, G. E. (2018). Enhancing creative cognition with a rapid right-parietal neurofeedback procedure. Neuropsychologia, 118(February), 99106.

doi.org/10.1016/j.neuropsychologia.20 18.02.015

Ashford, S., Edmunds, J., \& French, D. P. (2010). What is the best way to change self-efficacy to promote lifestyle and recreational physical activity? A systematic review with meta-analysis. British Journal of Health Psychology, 15(2), 265-288. doi.org/10.1348/135910709X461752

Boytos, A., Smith, K., \& Kim, J. H. (2017). The underdog advantage in creativity. Thinking Skills and Creativity, 26, 96101. doi.org/10.1016/j.tsc.2017.10.003

Burns, B. D., Zhang, Y., Wieth, M., \& Touyz, S. (2017). An exploratory study of creativity and eating disorders. Journal of Eating Disorders, 5(1), 536-556. doi.org/10.1186/s40337-017-0176-9

Bush, G. (2014). Fear no creativity. Knowledge Quest, 42(5), 20-23. Retrieved from search.proquest.com/docview/155099 2342? accountid=14777

Castillo-Vergara, M., Alvarez-Marin, A., \& Placencio-Hidalgo, D. (2018). A 
bibliometric analysis of creativity in the field of business economics. Journal of Business Research, 85(December 2017), 1-9. doi.org/10.1016/j.jbusres.2017.12.011

Chan, S., \& Yuen, M. (2014). Personal and environmental factors affecting teachers' creativity-fostering practices in Hong Kong. Thinking Skills and Creativity, 12, 69-77. doi.org/10.1016/j.tsc.2014.02.003

Chang, S. H., Wang, C. L., \& Lee, J. C. (2016). Do award-winning experiences benefit students' creative self-efficacy and creativity? The moderated mediation effects of perceived school support for creativity. Learning and Individual Differences, 51, 291-298. doi.org/10.1016/j.lindif.2016.09.011

Choi, J. N. (2004). Person - environment fit and creative behavior: Differential impacts of supplies - values and demands - abilities. Human Relations, 57(5), 531-552. doi.org/10.1177/0018726704044308

Collard, P., \& Looney, J. (2014). Nurturing creativity in education. European Journal of Education, 49(3), 348-364. doi.org/10.1111/ejed.12090

de Alencar, E. M. S. (2014). Maria Helena Novaes - creative person, creative life. Gifted Education International, 30(2), 99-105. doi.org/10.1177/0261429413481118

Delis, D. C., Lansing, A., Houston, W. S., Wetter, S., Han, S. D., Jacobson, M., ... Kramer, J. (2007). Creativity lost: The importance of testing higher-level executive functions in school-age children and adolescents. Journal of Psychoeducational Assessment, 25(1), 29-40. doi.org/10.1177/0734282906292403

Gajda, A. (2016). The relationship and moderators of school achievement and creativity at different educational stages. Thinking Skills and Creativity, 19 ,

246-259. doi.org/10.1016/j.tsc.2015.12.004

Gralewski, J., \& Karwowski, M. (2018). Are teachers' implicit theories of creativity related to the recognition of their students' creativity? Journal of Creative Behavior, 52(2), 156-167. doi.org/10.1002/jocb.140

Gulliksen, M. S. (2017). Making matters? Unpacking the role of practical aesthetic making activities in the general education through the theoretical lens of embodied learning. Cogent Education, 4(1), 1-14. doi.org/10.1080/2331186X.2017.1415 108

Hansenne, M., \& Legrand, J. (2012). Creativity, emotional intelligence, and school performance in children. International Journal of Educational Research, 53, 264-268. doi.org/10.1016/j.ijer.2012.03.015

Hoffmann, J., Ivcevic, Z., \& Brackett, M. (2016). Creativity in the age of technology: Measuring the digital creativity of millennials. Creativity Research Journal, 28(2), 149-153. doi.org/10.1080/10400419.2016.1162 515

Jahnke, I., Haertel, T., \& Wildt, J. (2017). Teachers' conceptions of student creativity in higher education. Innovations in Education and Teaching International, 54(1), 87-95. doi.org/10.1080/14703297.2015.1088 396

Jauk, E., Benedek, M., \& Neubauer, A. C. (2014). The road to creative achievement: A latent variable model of ability and personality predictors. European Journal of Personality, $28(1)$ 95-105. doi.org/10.1002/per.1941

Kaufman, J. C., \& Beghetto, R. A. (2013). In praise of Clark Kent: Creative metacognition and the importance of teaching kids when (not) to be creative. Roeper Review, 35(3), 155165.

doi.org/10.1080/02783193.2013.7994 
13

Konstantinidou, E., Gregoriadis, A., Grammatikopoulos, V., \& Michalopoulou, M. (2014). Primary physical education perspective on creativity: The nature of creativity and creativity fostering classroom environment. Early Child Development and Care, 184(5), 766782.

doi.org/10.1080/03004430.2013.8189 89

Konstantinidou, E., Zisi, V., Katsarou, D., \& Michalopoulou, M. (2015). Barriers and inhibitors of creativity in physical education. European Psychomotricity Journal, 7, 17-31. Retrieved from search.ebscohost.com/login.aspx?direc $\mathrm{t}=$ true \&db=a9h\&AN=119793540\&sit $\mathrm{e}=$ ehost-live $\&$ scope $=$ site

Krumm, G., Aranguren, M., Arán Filippetti, V., \& Lemos, V. (2016). Factor Structure of the torrance tests of creative thinking verbal form B in a Spanish-speaking population. Journal of Creative Behavior, 50(2), 150-164. doi.org/10.1002/jocb.76

Lucas, B. (2016). A five-dimensional model of creativity and its assessment in schools. Applied Measurement in Education, 29(4), 278-290. doi.org/10.1080/08957347.2016.1209 206

Lucas, B., Claxton, G., \& Spencer, E. (2013). Progression in student creativity in school: First steps towards new forms of formative assessments. OECD Education Working Papers, 86(86), 45. doi.org/10.1787/5k4dp59msdwk-en

Maksić, S., \& Pavlović, J. (2011). Educational researchers' personal explicit theories on creativity and its development: A qualitative study. High Ability Studies, 22(2), 219-231. doi.org/10.1080/13598139.2011.6288 50

Peterson, C., \& Seligman, M. E. P. (2004). Character strengths and virtues: $A$ handbook and classification. United States of America: American Psychological Association.

Ramdani, Z. (2018). Kolaborasi antara kepala sekolah, guru dan siswa dalam menciptakan sistem pendidikan yang berkualitas. In National Conference on Educational Assessment and Plolicy. Jakarta: Balai Pusat Penelitian (Balitbang) Kementrian Pendidikan dan Kebudayaan Republik Indonesia.

Ramdani, Z., \& Fahmi, I. (2014). Profil kekuatan karakter dan kebajikan pada mahasiswa berprestasi. Psympathic, 1 , 98-108. doi.org/10.15575/psy.vli1.471

Rinkevich, J. L. (2011). Creative teaching: Why it matters and where to begin. The Clearing House: A Journal of Educational Strategies, Issues and Ideas, 84(5), 219-223. doi.org/10.1080/00098655.2011.5754 16

Runco, M. A., Millar, G., Acar, S., \& Cramond, B. (2010). Torrance tests of creative thinking as predictors of personal and public achievement: A fifty-year follow-up. Creativity Research Journal, 22(4), 361-368. doi.org/10.1080/10400419.2010.5233 93

Seng, Q. K., Keung, H. K., \& Cheng, S. K. (2008). Implicit theories of creativity: A comparison of student-teachers in Hong Kong and Singapore. Compare, $38(1)$, 71-86. doi.org/10.1080/03057920701419959

Soriano, E. M. L. (1985). Creativitv in Brazilian Schools. GCT, 17.

Strenberg, R. J. (2006). The nature of creativity. Creativity Research Journal, 18(1), 87-98. doi.org/10.1207/s15326934crj1801

Taylor, M. A., \& Callahan, J. L. (2005). Bringing creativity into being: Underlying assumptions that influence methods of studying organizational creativity. Advances in Developing Human Resources, 7(2), 247-270. 
doi.org/10.1177/1523422305274529

Thoring, K., Desmet, P., \& Badke-Schaub, P. (2018). Creative environments for design education and practice: A typology of creative spaces. Design Studies, 56, 54-83. doi.org/10.1016/j.destud.2018.02.001

Warren, F., Mason-Apps, E., Hoskins, S., Azmi, Z., \& Boyce, J. (2018). The role of implicit theories, age, and gender in the creative performance of children and adults. Thinking Skills and Creativity, 28(2010), 98-109. doi.org/10.1016/j.tsc.2018.03.010
Zhou, J., Shen, J., Wang, X., Neber, H., \& Johji, I. (2013). A cross-cultural comparison: Teachers' conceptualizations of creativity. Creativity Research Journal, 25(3), 239-247. doi.org/10.1080/10400419.2012.7300 06 
Psympathic, Jurnal Ilmiah Psikologi Desember 2018, Vol. 5, No. 2, Hal. : 187-200 